\title{
Влияние сортовых особенностей на количественные потери семенного и продовольственного картофеля при хранении
}

\author{
Шайдулина Татьяна Борисовна \\ Кузбасская государственная сельскохозяйственная академия \\ Адрес: 650056, г. Кемерово, ул. Марковщева, д. 5 \\ E-mail: tanechka42rus@yandex.ru \\ Кондратенко Екатерина Петровна \\ Кузбасская государственная сельскохозяйственная академия \\ Адрес: 650056, г. Кемерово, ул. Марковщева, д. 5 \\ E-mail: nir@ksai.ru \\ Соболева Ольга Михайловна \\ Кемеровский государственный медицинский \\ университет Министерства здравоохранения РФ, \\ Адрес: 650056, г. Кемерово, ул. Ворошилова, д. 22 \\ E-mail:meer@yandex.ru \\ Сартакова Оксана Алексеевна \\ Кузбасская государственная сельскохозяйственная академия \\ Адрес: 650056, г. Кемерово, ул. Марковцева, д. 5 \\ E-mail: oksana_sartakova@mail.ru \\ Филипович Лариса Анатольевна \\ Кузбасская государственная сельскохозяйственная академия \\ Адрес: ул.Марковцева, 5, Кемерово, 650056 \\ E-mail:laf.47@yandex.ru \\ Мирошина Татьяна Александровна \\ Кузбасская государственная сельскохозяйственная академия \\ Адрес: 650056, г. Кемерово, ул. Марковцева, д. 5 \\ E-mail:intermir42@mail.ru
}

\begin{abstract}
Послеуборочное управление качеством клубней картофеля направлено на продление периода покоя и уменьшение потерь. Объектами исследований являлись клубни картофеля сортов Зекура, Гала, Ред Скарлет, Розара и Невский. Закладка опытов и количественные потери при хранении были определены по методике К.А. Пшеченкова с соавторами (2003) путем учета убыли массы (естественная убыль) и абсолютного отхода. Убыль массы определяли путем взвешивания фиксированных сеток. При хранении партии семенного картофеля в количестве 1500 тонн естественная убыль массы в среднем по сортам составляла 7,4 \%, а абсолютный отход - 3,7 \%. Убыль массы не превышала утвержденные нормативные нормы - 7,3 \%. Абсолютный отход за счет гнили также был незначительным. Хорошую сохранность клубней мы связываем с тем, что в хозяйстве перед посадкой клубни семенного и продовольственного картофеля обрабатывают инсекто-фунгицидным протравителем Престиж с нормой расхода 10 л/т. Немаловажным является и соблюдение режима хранения (оптимум в основной период хранения (октябрь, ноябрь) лежит в пределах $+3{ }^{\circ} \mathrm{C}$, декабрь, январь, февраль, март от $+1,5{ }^{\circ} \mathrm{C}$ до $+2{ }^{\circ} \mathrm{C}$, OВB $-90 \% \ldots 93 \%$; апрель $+4{ }^{\circ} \mathrm{C} \ldots+5{ }^{\circ} \mathrm{C}$ (семенной), ОВВ составляет 93 \%...95\%). При хранении продовольственного картофеля потери за счет
\end{abstract}


естественной убыли и абсолютного отхода были выше на 5,12 \% и 1,47 \% по сравнению с потерями семенного картофеля. Максимальные общие потери продовольственного картофеля при одном режиме хранения составляли у сорта Невский - 21,02 \%, минимальные у сорта Гала - 14,7 \%. Хорошо сохраняется сорт Зекура, потери за 9 месяцев хранения составляли $15,1 \%$.

Ключевые слова: картофель, сорт, хранение, убыль массы, абсолютный отход, общие потери

\section{Введение}

По данным Федеральной службы государственной статистики за 2019 год, картофель в Российской Федерации является одной из основных сельскохозяйственных культур, уступив зерновым (в т. ч. зернобобовым) и сахарной свекле. Валовой сбор его составляет 22,1 млн. тонн, урожайность - 17,8 т/га, что свидетельствует о довольно низком показателе, так как потенциал сортов, выращиваемых на территории России, не реализован даже наполовину ${ }^{1}$.

В настоящее время сорту в сельском хозяйстве уделяется много внимания (Пшеченков \& Давыденкова, 2003; Пшеченков, Зейрук, Еланский, Мальцев, \& Прямов, 2016; Lyubimova \& Eremin, 2018; Зейрук, Мальцев, Васильева, \& Бызов, 2019). Оптимальная сортовая структура той или иной культуры позволяет максимально эффективно использовать ресурсы за счет варьирования продолжительности вегетационного периода, минимизации влияния погодно-климатических факторов, оптимизации процесса уборки, послеуборочной доработки, хранения и реализации продукции. В результате рентабельность таких товаропроизводителей увеличивается. Этот вопрос становится важным в связи с расширением экспорта сельскохозяйственной продукции, особенно картофеля, внутри Евразийского экономического союза (Нечаев, Писарев, \& Писарева, 2018).

По данным В.Н. Зейрука с соавторами для лучшей сохранности клубней картофеля следует использовать обработку клубней химическими и биологическими препаратами Максим, Агат $25 \mathrm{~K}$, Вист, а также внедрять в производство систему активной вентиляции «Агро-7-Микроклимат» с автоматическим поддержанием оптимального температурно-влажностного режима (Зейрук, Мальцев, Васильева, \& Бызов, 2019). Так, например, использование гидрофобного наносиликата для обработки клубней картофеля перед хранением предотвращает прорастание (Zhang, et al., 2018).
Согласно утверждению С.В. Мальцева с соавторами для хранения семенного картофеля необходимо использовать химические и физические методы воздействия на клубни (Мальцев, Абросимов, \& Абашкин, 2019).

Сорта картофеля, обладающие стабильно высокой урожайностью, адаптивностью к различным условиям окружающей среды и другими ценными свойствами, например, устойчивостью к болезням и вредителям, высоко ценятся практиками (Pakul, Lapshinov, Gantimurova, \& Kulikova, 2019).

В то же время сложившаяся ситуация с использованием имеющихся отечественных сортов картофеля требует серьезного улучшения. Из внесенных в Госреестр сортов только половина принадлежит разработкам российских селекционеров (Жевора, Анисимов, Симаков, Овэс, \& Зебрин, 2019).

Однако даже внесение в Госреестр селекционных достижений еще не гарантирует коммерческий успех сорта у реальных товаропроизводителей. Поэтому в структуре посевных площадей доля отечественных сортов картофеля еще ниже. Большое количество иностранных сортов относительно российских особенно опасно в секторе крупнотоннажного производства картофеля, поскольку наметившаяся тенденция может создавать реальную угрозу дальнейшего уменьшения доли отечественных сортов (Osipov, Zhevora, \& Yanushkina, 2019), что ставит под угрозу продовольственную безопасность России.

Для поддержания качества убранных клубней необходимо длительное их хранение, часто с использованием промышленных установок. В связи с этим сохранение качества картофеля имеет решающее значение для разных целей использования - на семенные цели, для свежего потребления или для перерабатывающей промышленности (Alamar, Tosetti, Landahl, Bermejo, \& Leon 2017). Kaчество картофеля формируется в полевых условиях во время роста и развития растений и должно быть сохранено во время послеуборочной обработки и хранения (Ávila-Valdés, Quinet, Lutts,

\footnotetext{
1 Валовые сборы и урожайность сельскохозяйственных культур по Российской Федерации в 2019 году (2020). М.: Федеральная служба государственной статистики. URL: https://www.gks.ru/compendium/document/13277 (дата обращения: 03.02.2021).
} 
Martínez, \& Lizana, 2020). Абиотические факторы, влияющие на зрелость клубней, сортовую и сезонную изменчивость, оказывают большое влияние на итоговое качество клубней при хранении.

После уборки управление качеством клубней направлено на то, чтобы продлить период покоя и ограничить потерю веса и качества клубней картофеля. Процессы, происходящие при хранении клубней в картофелехранилищах, - это естественный процесс старения клубней (Draie \& Al-ABSI, 2018). Чтобы отсрочить этот процесс, крайне важны правильные условия хранения. На процесс старения влияет множество факторов, в том числе и сорт картофеля (Федотова, Тимошина, \& Князева, 2017; Elmore, et al., 2015).

Картофель хранят в специализированных хранилищах насыпью или в контейнерах. Основная задача состоит в снижении влажности на поверхности клубней. По данным К.А. Пшеченкова с соавторами, отобранные клубни картофеля помещают сразу на хранение и начинают лечебный период. Он необходим для заживления механических повреждений, полученных в ходе проведения комплекса полевых работ, и удаления избыточной влаги с поверхностей клубней из-за интенсивного дыхания после уборки (Пшеченков \& Мальцев, 2010; Пшеченков, Мальцев, Зейрук, Сазонова, \& Клюев 2017; Stark, Thornton, \& Nolte, 2020). При длительном хранении картофеля необходимо в хранилище поддерживать температурно-влажностный режим для сохранения качественных показателей клубней (Grudzińska \& Mańkowski, 2018; Kedia, Kausley, \& Rai, 2020; Valencia-Flórez, Trejo Escobar, Latorre Vásquez, Benavides, \& Mejía España, 2019; Basie, Bekuzarova, Gazzaev, Dzedaev, \& Tsarikaev, 2021).

Температура хранения в этот период должна составлять $+15^{\circ} \mathrm{C} \ldots+18{ }^{\circ} \mathrm{C}$, относительная влажность воздуха (ОВВ) $95 \%$ на протяжении 7...10 суток. Затем картофель постепенно охлаждают в течение 20-30 суток до установления в хранилище температуры $+2{ }^{\circ} \mathrm{C} \ldots+4{ }^{\circ} \mathrm{C}$.

В настоящее время существенным остается количество потерь при хранении, которое может оцениваться на уровне 1,5 млн. т. Одним из направлений решения проблем картофелеводства в Российской Федерации называется, в том числе, и разработка эффективных технологий уборки, хранения и защиты картофеля от патогенов и абиотических стрессов. Изучение сортовой изменчивости в структуре количественных потерь картофеля при хранении представляется актуальным (Prajapati, Patel, \& Gami, 2020). В связи с этим поставлена цель - исследовать влияние сортовых особенностей на количественные потери при длительном хранении семенного и продовольственного картофеля в условиях реальной сельскохозяйственной организации.

\section{Исследование}

\section{Материалы}

Объектами исследований являлись клубни картофеля 4-х сортов иностранной селекции Зекура, Гала, Ред Скарлет, Розара и один отечественной селекции Невский. Выбор определялся востребованностью этих сортов населением Кузбасса и другими регионами Российской Федерации, а также тем, что все сорта внесены в Государственный реестр селекционных достижений.

Сорт Гала, по данным Государственного реестра селекционных достижений, внесен в реестр в 2008 году. Сорт иностранной селекции (Германия). Раннеспелый, столового назначения. Растение средней высоты, многостебельное. Клубни и мякоть желтые. Глазки мелкие. Урожайность 30-50 т/га. Масса товарного клубня 120-150 г. Содержание крахмала 12-15 \%. Пластичный сорт. Ценность сорта: высокая урожайность и товарность, устойчивость к комплексу болезней и хорошая сохраняемость в зимний период.

Сорт Зекура внесен в Государственный реестр в 1997 году. Сорт иностранной селекции (Германия). Среднеранний сорт, вегетационный период 90-100 дней. Масса товарного клубня 65-135 г. Цвет кожуры песчаный, мякоть желтая. Содержание крахмала - до $18 \%$. Сорт относят к диетическим из-за высокого содержания каротина. Преимущества: стабильность урожая и хорошая лежкость.

Сорт Ред Скарлет внесен в Государственный реестр в 2000 году. Сорт иностранной селекции (Нидерланды). Раннеспелый, вегетационный период 70-80 дней. Столового назначения. Клубни выровненные, цвет кожуры красный, мякоть желтая. Масса товарного клубня 60-125 г. Урожайность 27-28 т/га. Содержание крахмала 10,1-15,6 \%. Ценность сорта: хорошо адаптирован к климатическим условиям Сибири, высокая урожайность, продолжительная лежкость.

Сорт Розара иностранной селекции (Германия), принят Государственным реестром в 1996 году, раннеспелый, вегетационный период 70-80 дней, 
цвет кожуры клубней красный, мякоть желтая, неглубокие мелкие глазки, клубни ровные массой 81-115 г, урожайность 20-31 т/га. Клубни плохо хранятся в зимний период.

Сорт Невский российской селекции, внесен в Государственный реестр в 1982 году. Среднеранний столовый картофель, считается лучшим из отечественных, по урожайности приближается к голландским сортам, урожайность 38-50 т/га. Масса товарного клубня 90-130 г. Цвет кожуры желтый, мякоть кремовая. Содержание крахмала 10-12 \%. Лежкость хорошая.

\section{Методы исследования}

В СПК «Береговой» для сохранения больших партий картофеля применяют специализированные стационарные хранилища. Хранилище железобетонного типа, перегородки деревянные, полы бетонные, высотой 6,5 м с импортным оборудованием для контроля за процессом хранения. Контроль полностью автоматизирован. Исходный семенной материал перед закладкой на хранение не имел больных, механически поврежденных клубней и полностью соответствовал ГОСТу 33996-2016². В хозяйстве принята дифференцированная температура хранения: отобранный картофель в лечебный период (сентябрь) хранят при температуре $+15 \ldots+16^{\circ} \mathrm{C}$, относительная влажность воздуха (OBB) - 95 \%; оптимум в основной период хранения (октябрь, ноябрь) лежит в пределах $+3{ }^{\circ} \mathrm{C}$, декабрь, январь, февраль, март от $+1,5^{\circ} \mathrm{C}$ до $+2{ }^{\circ} \mathrm{C}$, ОВВ - $90 \% . .93 \%$; апрель $+4{ }^{0} \mathrm{C} . . .+5{ }^{\circ} \mathrm{C}$ (семенной), ОВВ составляет 93 \%...95 \%. Продовольственный картофель хранят 9 месяцев до мая включительно. Количественные потери при хранении были определены за весь период хранения путем учета убыли массы (естественная убыль) и абсолютного отхода. Убыль массы определяли путем взвешивания фиксированных сеток до и после хранения на технических весах. Опыт закладывали по методике К.А. Пшеченкова с соавторами (2003). В каждом хранилище в трёх зонах на глубину 0,5 м от верха закладывали контрольные сетки в пятикратной повторности в каждой зоне, отступив от боковых стен на 1 м. Всего на одно хранилище было заложено 15 сеток, каждого сорта по три сетки. Сетки по линии закладывали равномерно, на равном расстоянии друг от друга. Масса картофеля в каждой сетке 10 кг. Каждую сетку снабжали этикеткой из клеёнки, в которой указывалась масса, номер, сорт и дата закладки. По каждой сетке расчёт проводили отдельно, а затем рассчитывали средний показатель по зонам и в среднем по хранилищу. На основании полученных данных определяли потери в целом за период хранения. Исходное качество закладываемого картофеля определяли на основании клубневого анализа по средней пробе из 100 клубней, составленной из разных мест насыпи картофеля. Повторность трёхкратная.

Математическую обработку проводили по методике Б.А. Доспехова ${ }^{3}$.

\section{Процедура исследования.}

Исследования проведены в СПК «Береговой» Кемеровской области расположенного на юго-востоке Западной Сибири в 2019-2020 гг. Почва - чернозем выщелоченный тяжелосуглинистый с содержанием гумуса в слое 0-20 см - 7-9 \%, pH = 5,3. Климат резко континентальный, среднегодовая сумма осадков 350-450 мм. Сумма положительных температур выше $+10{ }^{\circ} \mathrm{C}$ составляет $1800-1900{ }^{\circ} \mathrm{C}$, среднемноголетняя величина ГТК - 1,2 , что характеризует данную территорию как умеренно увлажненную. 2019 год характеризовался как вполне благоприятный для выращивания картофеля.

Зяблевую вспашку проводили осенью плугом ПН3-35 на глубину 27 см. Весной при достижении физической спелости почвы проводили культивацию CMАРАГТ-8, доминирование DM-4000, а затем с минимальным разрывом по времени проводили посадку клубней картофеля четырехрядной картофелесажалкой с навигационной системой GRIMME GL-34 T. Для посадки использовали клубни массой 60-80 г. Густота посадки в среднем 3-4 тыс. кг на гектар, высота гребней 30 см. Семенной материал с переборкой и калибровкой на фракции подготавливали за 2-3 недели до посадки. Посадку проводили в первой декаде мая. Предшественник - зерновые.

Междурядья составляли 75 см, посадку клубней проводили на глубину 6-8 см с одновременным локальным внесением минеральных удобрений диаммофоски с соотношением азота $10 \%$, фосфора и калия по 26 \% из расчёта 450-500 кг/га в физическом весе.

Непосредственно во время посадки в сошнике картофелесажалки клубни обрабатывали универ-

\footnotetext{
ГОСТ 33996-2016. (2016). Картофель семенной. Технические условия и методы определения качества. М.: Стандартинформ.

3 Доспехов, Б. А. (2011). Методика полевого опыта: Учебник для студентов высших сельскохозяйственных учебных заведений по агрономическим специальностям. М.: Альянс.
} 
сальным препаратом Престиж из расчета 10 л/га для борьбы с проволочником и колорадским жуком, а также против болезней при хранении. Для борьбы с однолетними и многолетними сорняками использовали послевсходовый гербицид Титус, СТС с нормой расхода 50 г/га. Обработку проводили опрыскивателем AMAZONE-3000. Уборку осуществляли картофелеуборочным комбайном GRIMME-SE 150-60.

Для послеуборочной обработки картофеля использовали сортировальный пункт КСП-15, где отделяли землю, мелкие, поврежденные и больные клубни. Отсортированный картофель транспортерами SH-200 подают к транспортеру укладчику SE-250, который формирует насыпь в секциях высотой 3м для семенного картофеля и 4 м с использованием установок активного вентилирования.

\section{Результаты исследования}

\section{и их обсуждение}

Полученный урожай картофеля хозяйство СПК «Береговой» распределяет по нескольким направлениям (Таблица 1). В 2019 г. с площади 4295 га в среднем при урожайности 47 т/га предприятие собрало 20500 тонн картофеля.

Следует отметить, что переработкой картофеля предприятие не занимается, в основном реализует свежий урожай, хранит семенной до мая и продовольственный картофель до июня включительно.

Как видно из Таблицы 1 , хозяйство реализует картофель на рынках сразу после уборки урожая в количестве 9000 тонн. Семенной картофель в количестве
1500 тонн и продовольственный в количестве 9000 тонн хранят до июня включительно. Картофель с механическими повреждениями, мелкие клубни в количестве 1000 тонн идет на корм скоту.

При хранении партии семенного картофеля с сентября по апрель (8 месяцев) в количестве 1500 тонн естественная убыль массы в среднем составляла 7,4 \%, а абсолютный отход $-4,0 \%$. Сoртовое распределение этого показателя представлено на Рисунке 1.

Анализ потерь при хранении семенного картофеля показывает, что лучше сохраняются такие сорта иностранной селекции, как Зекура, Гала и Ред Скарлет. В результате процессов дыхания и испарения воды при хранении происходит естественная убыль массы. Путем взвешивания фиксированных проб картофеля (заложенных в сетках) был рассчитан процент убыли массы. Естественная убыль сортов Зекура, Гала и Ред Скарлет была относительно низкой и составила $6 \%$...7 \%. У сортов Розара и Невский этот показатель составлял $9 \%$, что в 1,4 раза больше, чем у вышеперечисленных сортов.

За счет поражения клубней семенного картофеля болезнями, а также за счет гнили и порчи грызунами за весь период хранения (абсолютный отход) потери по сортам были небольшие и составляли от 3 \% (Ред Скарлет) до 5 \% (Розара).

Как видно из расчетов, представленных в Таблице 2, убыль массы в физическом весе по сортам была неодинаковой и колебалась от 18,0 т (Heвский) до 24,5 т (Зекура). Коэффициент вариации составил $\mathrm{V}=27 \%$, что ниже $30 \%$. Это говорит о небольшой вариации естественной убыли по сортам. Общие потери за 8 мес. хранения семенного картофеля составляли 11,09 \%. Минимальные по-

Таблица 1

Производство и распределение картофеля, СПК «Береговой», 2019 г.

\begin{tabular}{|c|c|c|c|c|c|c|c|}
\hline \multirow[t]{2}{*}{ Сорт } & \multirow{2}{*}{$\begin{array}{c}\text { Площадь } \\
\text { посадки, га }\end{array}$} & \multirow{2}{*}{$\begin{array}{c}\text { Урожай- } \\
\text { ность, т/га }\end{array}$} & \multirow{2}{*}{$\begin{array}{c}\text { Валовой } \\
\text { сбор, т }\end{array}$} & \multicolumn{4}{|c|}{ Распределение } \\
\hline & & & & $\begin{array}{c}\text { реали- } \\
\text { зация, т }\end{array}$ & семена, т & $\begin{array}{c}\text { продоволь- } \\
\text { ственный, т }\end{array}$ & $\begin{array}{c}\text { на корм, } \\
\text { кг }\end{array}$ \\
\hline Гала & 97,0 & 50,0 & 4850 & 2500 & 350 & 1900 & 100 \\
\hline Ред Скарлет & 117,0 & 50,0 & 5850 & 2500 & 350 & 2900 & 100 \\
\hline Зекура & 85,5 & 45,0 & 3847,5 & 1500 & 347,5 & 1900 & 100 \\
\hline Розара & 75,0 & 50,0 & 3750 & 1500 & 250 & 1650 & 350 \\
\hline Невский & 55,0 & 40,0 & 2200 & 1000 & 200 & 650 & 350 \\
\hline Итого & 4295 & 47,0 & 20500,0 & 9000 & 1500 & 9000 & 1000 \\
\hline
\end{tabular}




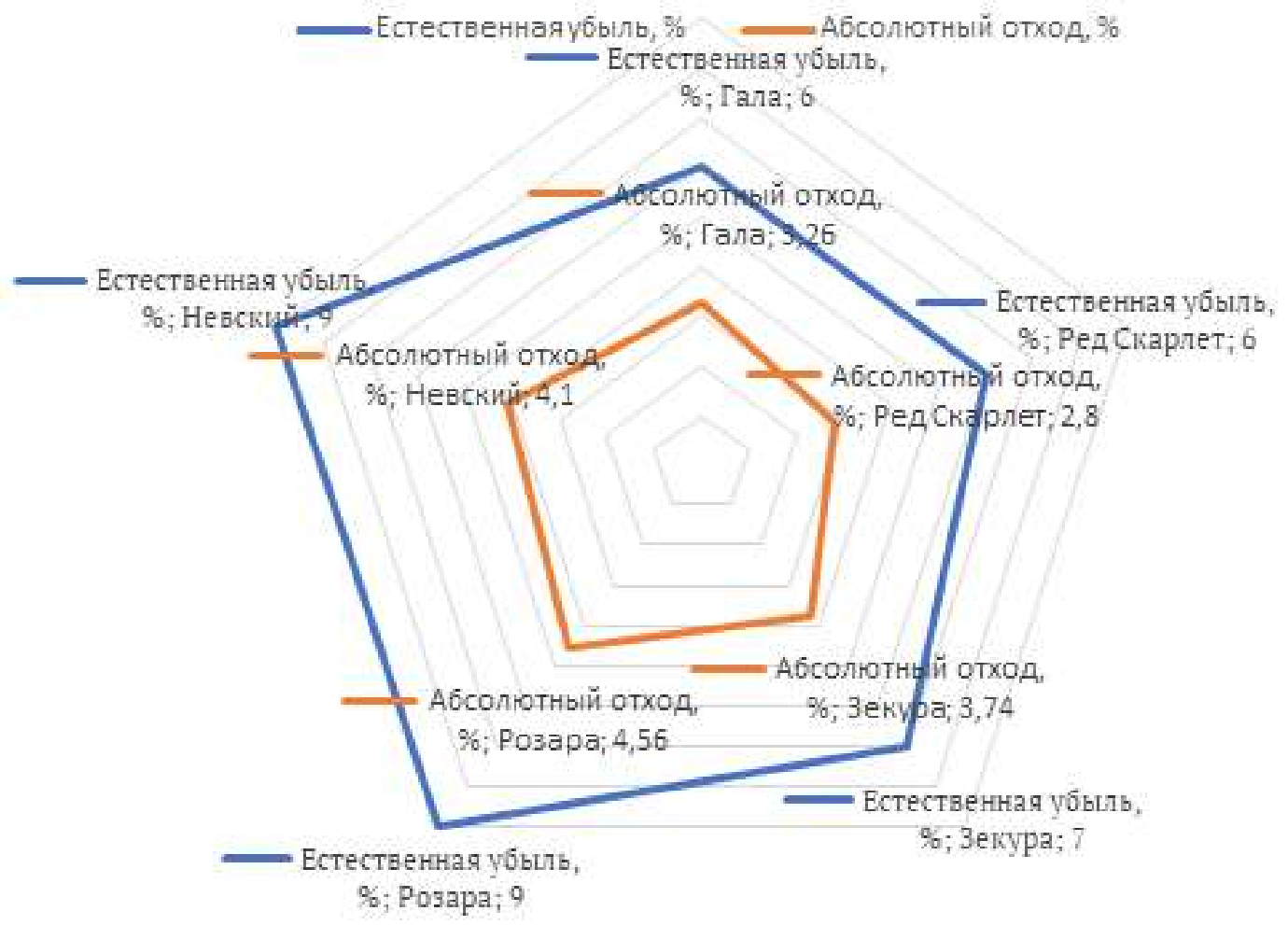

Рисунок 1. Потери за 8 месяцев (сентябрь-апрель) хранения семенного картофеля в СПК «Береговой», \%

тери выявлены у сорта Ред Скарлет 8,8 \%, а максимальные у сорта Розара 13,56 \%. Коэффициент вариации составил $\mathrm{V}=30,1 \%$.
Анализ хранения продовольственного картофеля показал, что общие потери после 9 месяцев хранения составляли $17,7 \%$

Таблица 2

Общие количественные потери (тонн) картофеля при длительном хранении, СПК «Береговой», 20192020 г2.

\begin{tabular}{|c|c|c|c|c|c|c|}
\hline Сорт & $\begin{array}{l}\text { Естественная } \\
\text { убыль массы }\end{array}$ & $\%$ & $\begin{array}{c}\text { Абсолют- } \\
\text { ный отход }\end{array}$ & $\%$ & $\begin{array}{l}\text { Общие } \\
\text { потери }\end{array}$ & $\%$ \\
\hline \multicolumn{7}{|c|}{ семенной картофель } \\
\hline Гала & 21,00 & 6,00 & 11,40 & 3,26 & 32,40 & 9,26 \\
\hline Ред Скарлет & 21,00 & 6,00 & 9,80 & 2,80 & 30,80 & 8,80 \\
\hline Зекура & 24,50 & 7,00 & 13,00 & 3,74 & 37,50 & 10,74 \\
\hline Розара & 22,50 & 9,00 & 11,40 & 4,56 & 33,90 & 13,56 \\
\hline Невский & 18,00 & 9,00 & 8,20 & 4,10 & 26,20 & 13,10 \\
\hline Итого & 107,00 & 7,40 & 53,80 & 3,70 & 160,80 & 11,09 \\
\hline \multicolumn{7}{|c|}{ продовольственный картофель } \\
\hline Гала & 190,0 & 10,00 & 89,30 & 4,70 & 279,3 & 14,70 \\
\hline Ред Скарлет & 362,0 & 12,50 & 164,90 & 5,70 & 526,9 & 18,20 \\
\hline Зекура & 203,3 & 10,70 & 84,90 & 4,47 & 288,2 & 15,17 \\
\hline Розара & 206,2 & 13,30 & 93,80 & 6,05 & 300,0 & 19,35 \\
\hline Невский & 105,0 & 16,10 & 32,00 & 4,92 & 137,0 & 21,02 \\
\hline Итого & 1066,5 & 12,52 & 464,90 & 5,17 & 1531,4 & 17,70 \\
\hline
\end{tabular}




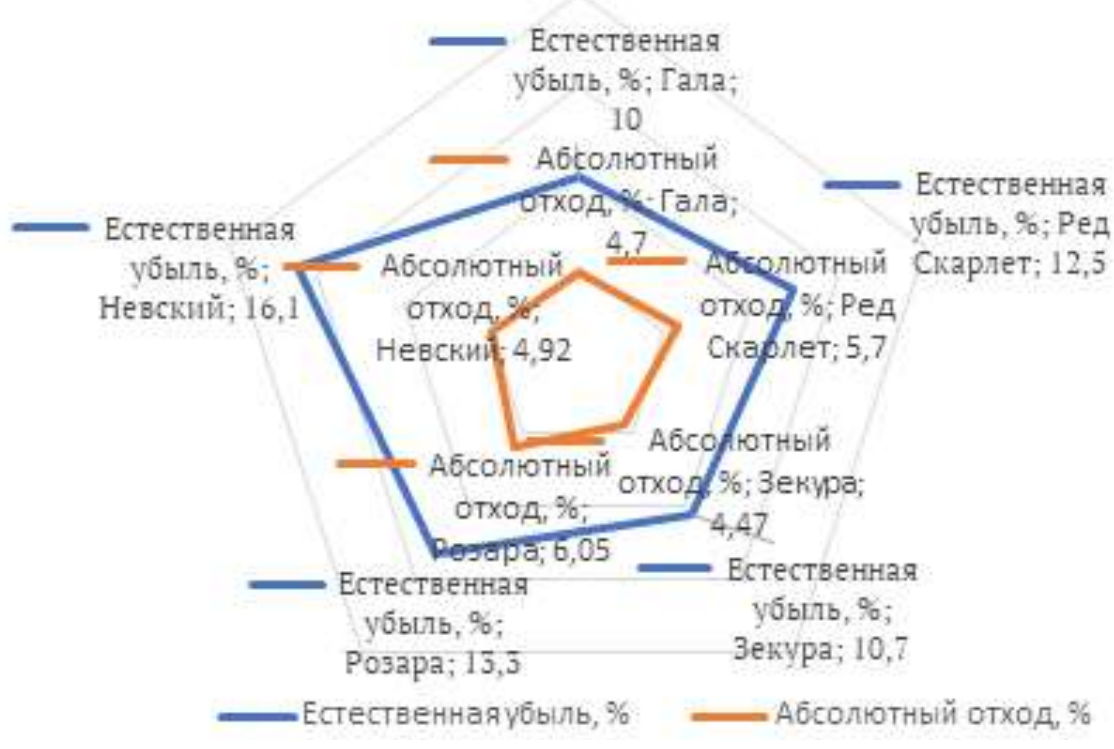

Рисунок 2. Потери за 9 месяцев хранения продовольственного картофеля в СПК «Береговой», \%

При хранении партии продовольственного картофеля (Рисунок 2) в количестве 9000 тонн естественная убыль массы в общем по сортам составила $12,52 \%$, а абсолютный отход $-5,17 \%$. По сортам наблюдаются колебания в потерях в массе за счет естественной убыли (дыхания и испарения воды) от 10,0 \% (Гала) до 16,1 \% (Невский), за счет абсолютного отхода в среднем по сортам 5,17 \%, общие потери в зависимости от сорта составляли 14,7 \%...21\%. Потери продовольственного картофеля за счет абсолютного отхода в среднем были выше на 1,47 \%, чем при хранении семенного картофеля.

Потери в физическом весе продовольственного картофеля за счет естественной убыли колебались в зависимости от сортовых особенностей и массы, заложенной на хранение, от 105 т (Невский) до 362 т (Ред Скарлет). Выявлено, что абсолютный отход за 9 мес. хранения также варьировал от 32 т (Невский) до 164,9 т (Ред Скарлет).

Общие потери при хранении продовольственного картофеля составляли у сортов Ред Скарлет $18,2 \%$, Гала - 14,7 \%, Зекура - 15,17 \%, Невский - 21,0 \%, Розара - 19,35 \%.

Таким образом, необходимо внедрять в производство систему активной вентиляции с автоматическим поддержанием оптимального температурно-влажностного режима и проводить подбор сортов с длительным сроком хранения, на что указывают работы исследователей В.Н. Зейрука и К.А. Пшеченкова с соавторами.

\section{Выводы}

Таким образом, при хранении с сентября 2019 года по апрель 2020 года семенного картофеля навалом при высоте насыпи 3 м максимальные потери в стационарном хранилище с использованием установок активного вентилирования при температуре основного периода хранения $+2{ }^{\circ} \mathrm{C} . . .+5{ }^{\circ} \mathrm{C}$ составляли у сортов Розара 13,56 \%, Невский 13,1\%. Хорошо сохраняются сорта Ред Скарлет и Гала; их общие потери составляли от 8,8 \% до 9,26\% соответственно.

При хранении продовольственного картофеля при высоте насыпи 4 м в стационарном хранилище на установках активного вентилирования при температуре хранения $+1,5^{\circ} \mathrm{C} \ldots+4{ }^{\circ} \mathrm{C}$ за 9 месяцев хранения общие потери составляли $17,7 \%$.

При правильно подобранных сортах, хорошо организованной агротехнике возделывания семенного и продовольственного картофеля и при хорошей организации послеуборочной обработки и соблюдении режима хранения клубней картофеля в СПК «Береговой» общие потери при длительном сроке хранения незначительные. Общие потери для семенного картофеля составляли 11,09 \%, а продовольственного $17,7 \%$. Установлено, что на общие потери при хранении влияют сортовые особенности культуры.

\section{Литература}

Жевора, С. В., Анисимов, Б. В., Симаков, Е. А., Овэс, Е. В., \& Зебрин, С. Н. (2019). Картофель: 
Проблемы и перспективы. Картофель и овощи, 7, 2-7. https://doi.org/10.25630/PAV.2019.89.92.006

Зейрук, В. Н., Мальцев, С. В., Васильева, С. В., \& Бызов, В. А. (2019). Современные производственные факторы, определяющие биологическую и экономическую эффективность хранения картофеля. Хранение и переработка сельхозсырья, 3, 2028. https://doi.org/10.36107/spfp.2019.177

Мальцев, С. В., Абросимов, Д. В., \& Абашкин, О. В. (2019). Хранение семенного картофеля с использованием химических и физических методов воздействия на клубни. Картофель и овощи, 5, 31-34. https://doi.org/10.25630/PAV.2019.30.88.007

Нечаев, В. И., Писарев, С. Л., \& Писарева, Л. В. (2018). Организационный механизм формирования и развития рынка семенного картофеля в странах содружества ЕАЭС. АПК: Экономика, управление, 10, 106-111. https://doi. org/10.33305/1810-106

Пшеченков, К. А., \& Давыденкова, О. Н. (2003). Потребительские качества клубней и хранение картофеля в зависимости от сорта, условий выращивания и хранения. В Вопросы картофелеводства: Научные труды (с. 90-99). М.: ВНИИКХ.

Пшеченков, К. А., \& Мальцев, С. В. (2010). Методические рекомендации по технологии хранения различных сортов картофеля. М.: ВНИИКХ.

Пшеченков, К. А., Зейрук, В. Н., Еланский, С. Н., Мальцев, С. В., \& Прямов, С. Б. (2016). Хранение картофеля. М.: Агроспас.

Пшеченков, К. А., Мальцев, С. В., Зейрук, В. Н., Сазонова, 3. В., \& Клюев, С. И. (2017). Современные технологии хранения картофеля. М.: ВНИИКХ.

Федотова, Л. С., Тимошина, Н. А., \& Князева, Е. В. (2017). Динамика биохимических показателей картофеля в период хранения. Картофель и овощи, 1, 31-34.

Alamar, M. C., Tosetti, R., Landahl, S., Bermejo, A., \& Leon, A. T. (2017). Assuring potato tuber quality during storage: A future perspective. Frontiers in Plant Science, 8, 2034. https://doi.org/10.3389/ fpls.2017.02034

Ávila-Valdés, A., Quinet, M., Lutts, S., Martínez, J. P., Lizana, C. (2020). Tuber yield and quality responses of potato to moderate temperature increase during Tuber bulking under two water availability scenarios. Field Crops Research, 251, 107786. https://doi.org/10.1016/j.fcr.2020.107786

Basiev, S. S., Bekuzarova, S. A., Gazzaev, G. T., Dzedaev, Kh. T., \& Tsarikaev, Z. A. (2021). Effective means of potatoes storage. IOP Conference Series: Earth and Environmental Science, 677(2), 022099. https://doi.org/10.1088/1755-1315/677/2/022099

Draie, R., \& Al-ABSI, M. (2018). Regulation and control of potato tuber dormancy and sprouting.
International Journal of Recent Advances in Multidis ciplinary Research, 6(1), 4573-4583.

Elmore, J. E., Briddon, A., Dodson, A. T., Muttucumaru, N., Halford, N. G., \& Mottram, D. S. (2015). Acrylamide in potato crisps prepared from 20 UK-grown varieties: Effects of variety and tuber storage time. Food Chemistry, 182, 1-8. https://doi.org/10.1016/j. foodchem.2015.02

Grudzińska, M., \& Mańkowski, D. (2018). Losses during Storage of Potato Varieties in Relationto Weather Conditions duringthe Vegetation Period and Temperatures during Long-Term Storage. American Journal of Potato Research, 95(2), 130-138. https://doi.org/10.1007/s12230-017-9617-x

Kedia, P., Kausley, S. B., \& Rai, B. (2020). Temperature and humidity based models for the prediction of transpiration rate in potatoes during storage. Journal of Food Process Engineering, 44(3), e13626. https://doi.org/10.1111/jfpe.13626

Lyubimova, A., \& Eremin, D. (2018). Laboratory varietal control as a guarantee of successful work of agribusiness in Russia. MATEC Web of Conferences, 170, 04015. https://doi.org/10.1051/ matecconf/201817004015

Osipov, V., Zhevora, S., \& Yanushkina, N. (2019). Efficiency of potato production: analysis of variation and differentiation of regions of the Russian Federation. IOP Conference Series: Earth and Environmental Science, 274, 012060. https:// doi.org/10.1088/1755-1315/274/1/012060.

Pakul, V. N., Lapshinov, N. A., Gantimurova, A. N., \& Kulikova, V. I. (2019). Donors of potato (Solanum L.) plasticity and yield stability traits in the environmental conditions of north forest steppe of Western Siberia. Agricultural Biology, 54(5), 978-989. https://doi.org/10.15389/agrobiology.2019.5.978eng

Prajapati, D. R., Patel, R. N., \& Gami, R. A. (2020). Study of genetic variability of tuberyield and storagerelated traitsin potato (Solanumtuberosum L.). International Journal of Chemical Studies, 8(3), 188-192. https://doi. org/10.22271/chemi.2020.v8.i3c.9220

Stark, J. C., Thornton, M., \& Nolte, P. (2020). Potato Production Systems. Springer: Cham. https://doi. org/10.1007/978-3-030-39157-7

Valencia Flórez, L. F., Trejo Escobar, D. M., Latorre Vásquez, L. I., Benavides, A. M. H., \& Mejía España, D. F. (2019). Influence of storage conditions on the quality of two varieties of native potato (Solanum Tuberosum group phureja). Dyna, 86(209), 49-55. https://doi.org/10.15446/DYNA.V86N209.72958

Zhang, L., Li, M., Zhang, G., Wu, L., Cai, D., \& Wu, Z. (2018). Inhibiting Sprouting and Decreasing $\alpha$-Solanine Amount of Stored Potatoes Using Hydrophobic Nanosilica. ACS Sustainable Chemistry \& Engineering, 6(8), 10517-10525. https://doi.org/10.1021/acssuschemeng.8b01860 


\title{
Seed and Food Potato Variety Characteristic Influence on Quantitative Loss During Storage Period
}

\author{
Tatiana B. Shaidulina \\ Kuzbass State Agricultural Academy \\ 5, Markovtsev st., Kemerovo, 650056, Russian Federation \\ E-mail: tanechka42rus@yandex.ru \\ Ekaterina P. Kondratenko \\ Kuzbass State Agricultural Academy \\ 5, Markovtsev st., Kemerovo, 650056, Russian Federation \\ E-mail: nir@ksai.ru \\ Olga M. Soboleva \\ Kemerovo State Medical University of the Ministry \\ of Health of the Russian Federation \\ 22, Voroshilov st., Kemerovo, 650056, Russian Federation \\ E-mail:meer@yandex.ru \\ Oksana A. Sartakova \\ Kuzbass State Agricultural Academy \\ 5, Markovtsev st., Kemerovo, 650056, Russian Federation \\ E-mail:oksana_sartakova@mail.ru \\ Larisa A. Filipovich \\ Kuzbass State Agricultural Academy \\ 5, Markovtsev st., Kemerovo, 650056, Russian Federation \\ E-mail: laf.47@yandex.ru \\ Tatiana A. Miroshina \\ Kuzbass State Agricultural Academy \\ 5, Markovtsev st., Kemerovo, 650056, Russian Federation \\ E-mail: intermir42@mail.ru
}

\begin{abstract}
Post-harvest quality management of potato tubers is aimed at extending the dormancy period and reducing losses. The objects of research were potato tubers of varieties Zekura, Gala, Red Scarlet, Rosara and Nevsky. Test setting and quantitative storage losses were determined by the method of K.A. Pshechenkov et al (2002) by taking into account the loss in mass (natural loss) and absolute waste. The loss in mass was determined by weighing the fixed meshes. When storing a batch of seed potatoes in the amount of 1500 tons, the natural loss in weight on average for varieties was $7.4 \%$ and the absolute waste was $4.0 \%$. The mass loss did not exceed the approved normative norms of $7.3 \%$. The absolute decay due to rot was also negligible. We associate the good preservation of tubers with the treatment the tubers of seed potatoes before laying for storage with the Prestige fungicide with a consumption rate of $0.7-1.01 / t$ and observing the storage regime. During storage of food potatoes, losses due to natural loss and absolute waste were higher by $4.2 \%$ and $1.7 \%$ compared to losses of seed potatoes.
\end{abstract}

The maximum total loss of potatoes under one storage regime was $19 \%$ for the varieties Rosara and Red Scarlet, the minimum for the variety Gala - $15 \%$. The varieties Zekura and Nevsky are well preserved. Their losses over 9 months of storage were $15.7 \%$ and $16 \%$, respectively.

Key words: potatoes, variety, storage, weight loss, absolute waste, total losses, yield 


\section{References}

Fedotova, L. S., Timoshina, N. A., \& Knyazeva, E. V. (2017). Dinamika biokhimicheskikh pokazatelei kartofelya $\mathrm{v}$ period khraneniya [Dynamics of potato biochemical parameters during storage]. Kartofel' i ovoshchi [Potatoes and Vegetables], 1, 31-34.

Mal'tsev, S. V., Abrosimov, D. V., \& Abashkin, O. V. (2019). Khranenie semennogo kartofelya $\mathrm{s}$ ispol'zovaniem khimicheskikh i fizicheskikh metodov vozdeistviya na klubni [Storage of seed potato using chemical and physical methods of exposure to tubers]. Kartofel' $i$ ovoshchi [Potato and Vegetables], 5, 31-34. https://doi.org/10.25630/ PAV.2019.30.88.007

Nechaev, V. I., Pisarev, S. L., \& Pisareva, L. V. (2018). Organizatsionnyi mekhanizm formirovaniya i razvitiya rynka semennogo kartofelya v stranakh sodruzhestva EAES [Organizational mechanism for the formation and development of the seed potato market in the countries of the EAEU commonwealth]. APK: Ekonomika, upravlenie [AgroIndustrial Complex: Economics, Management], 10, 106-111. https://doi.org/10.33305/1810-106

Pshechenkov, K. A., \& Davydenkova, O. N. (2003). Potrebitel'skie kachestva klubnei i khranenie kartofelya v zavisimosti ot sorta, uslovii vyrashchivaniya i khraneniya [Consumer qualities of tubers and storage of potatoes, depending on the variety, growing conditions and storage]. In Voprosy kartofelevodstva: Nauchnye trudy [Questions of potato growing: Scientific works] (pp. 90-99). Moscow: VNIIKKh.

Pshechenkov, K. A., \& Mal'tsev, S. V. (2010). Metodicheskie rekomendatsii po tekhnologii khraneniya razlichnykh sortov kartofelya [Methodical recommendations for storage technology of various varieties of potatoes]. Moscow: VNIIKKh.

Pshechenkov, K. A., Mal'tsev, S. V., Zeiruk, V. N., Sazonova, Z. V., \& Klyuev, S. I. (2017). Sovremennye tekhnologii khraneniya kartofelya [Modern technologies for storing potatoes]. Moscow: VNIIKKh.

Pshechenkov, K. A., Zeiruk, V. N., Elanskii, S. N., .Mal'tsev, S. V., \& Pryamov, S. B. (2016). Khranenie kartofelya [Potato storage]. Moscow: Agrospas.

Zeiruk, V. N., Mal'tsev, S. V., Vasil'eva, S. V., \& Byzov, V. A. (2019). Sovremennye proizvodstvennye faktory, opredelyayushchie biologicheskuyu i ekonomicheskuyu effektivnost' khraneniya kartofelya [Modern production factors that determine the biological and economic efficiency of potato storage]. Khranenie i pererabotka sel'khozsyr'ya [Storage and Processing of Farm Products], 3, 20-28. https://doi.org/10.36107/spfp.2019.177

Zhevora, S. V., Anisimov, B. V., Simakov, E. A., Oves, E. V., \& Zebrin, S. N. (2019). Kartofel': Problemy i perspektivy [Potatoes: Problems and Prospects]. Kartofel' $i$ ovoshchi [Potatoes and Vegetables], 7, 2-7. https://doi. org/10.25630/PAV.2019.89.92.006

Alamar, M. C., Tosetti, R., Landahl, S., Bermejo, A., \& Leon, A. T. (2017). Assuring potato tuber quality during storage: A future perspective. Frontiers in Plant Science, 8, 2034. https://doi.org/10.3389/ fpls.2017.02034

Ávila-Valdés, A., Quinet, M., Lutts, S., Martínez, J. P., Lizana, C. (2020). Tuber yield and quality responses of potato to moderate temperature increase during Tuber bulking under two water availability scenarios. Field Crops Research, 251, 107786. https://doi.org/10.1016/j.fcr.2020.107786

Basiev, S. S., Bekuzarova, S. A., Gazzaev, G. T., Dzedaev, Kh. T., \& Tsarikaev, Z. A. (2021). Effective means of potatoes storage. IOP Conference Series: Earth and Environmental Science, 677(2), 022099. https://doi.org/10.1088/1755-1315/677/2/022099

Draie, R., \& Al-ABSI, M. (2018). Regulation and control of potato tuber dormancy and sprouting. International Journal of Recent Advances in Multidis ciplinary Research, 6(1), 4573-4583.

Elmore, J. E., Briddon, A., Dodson, A. T., Muttucumaru, N., Halford, N. G., \& Mottram, D. S. (2015). Acrylamide in potato crisps prepared from 20 UKgrown varieties: Effects of variety and tuber storage time. Food Chemistry, 182, 1-8. https://doi. org/10.1016/j.foodchem.2015.02

Grudzińska, M., \& Mańkowski, D. (2018). Losses during Storage of Potato Varieties in Relationto Weather Conditions duringthe Vegetation Period and Temperatures during Long-Term Storage. American Journal of Potato Research, 95(2), 130-138. https://doi.org/10.1007/s12230-017-9617-x

Kedia, P., Kausley, S. B., \& Rai, B. (2020). Temperature and humidity based models for the prediction of transpiration rate in potatoes during storage. Journal of Food Process Engineering, 44(3), e13626. https://doi.org/10.1111/jfpe.13626

Lyubimova, A., \& Eremin, D. (2018). Laboratory varietal control as a guarantee of successful work of agribusiness in Russia. MATEC Web of Conferences, 170, 04015. https://doi.org/10.1051/matecconf/201817004015

Osipov, V., Zhevora, S., \& Yanushkina, N. (2019). Efficiency of potato production: analysis of variation and differentiation of regions of the Russian Federation. IOP Conference Series: Earth and Environmental Science, 274, 012060. https://doi. org/10.1088/1755-1315/274/1/012060.

Pakul, V. N., Lapshinov, N. A., Gantimurova, A. N., \& Kulikova, V. I. (2019). Donors of potato (Solanum L.) plasticity and yield stability traits in the environmental conditions of north forest steppe of Western Siberia. Agricultural Biology, 54(5), 978-989. https://doi.org/10.15389/agrobiology.2019.5.978eng 
Prajapati, D. R., Patel, R. N., \& Gami, R. A. (2020). Study of genetic variability of tuberyield and storagerelated traitsin potato (Solanumtuberosum L.). International Journal of Chemical Studies, 8(3), 188-192. https://doi. org/10.22271/chemi.2020.v8.i3c.9220

Stark, J. C., Thornton, M., \& Nolte, P. (2020). Potato Production Systems. Springer: Cham. https://doi. org/10.1007/978-3-030-39157-7

Valencia Flórez, L. F., Trejo Escobar, D. M., Latorre Vásquez, L. I., Benavides, A. M. H., \& Mejía Espa- ña, D. F. (2019). Influence of storage conditions on the quality of two varieties of native potato (Solanum Tuberosum group phureja). Dyna, 86(209), 49-55. https://doi.org/10.15446/DYNA.V86N209.72958

Zhang, L., Li, M., Zhang, G., Wu, L., Cai, D., \& Wu, Z. (2018). Inhibiting Sprouting and Decreasing $\alpha$-Solanine Amount of Stored Potatoes Using Hydrophobic Nanosilica. ACS Sustainable Chemistry \& Engineering, 6(8), 10517-10525. https://doi.org/10.1021/acssuschemeng. $8 \mathrm{~b} 01860$ 